\title{
Industry slow to invest in German biotech...
}

Munich. Despite considerable political pressure, German industry remains cautious about putting its money into the government's newly launched human genome programme. While supporting the programme, most companies prefer to make their major investments in the United States, drawn by both the more advanced technical base, and by what some see as a more cooperative attitude in the research community.

Negotiations about industry's involvement in the programme have been dragging on about the type of body that should be set up to exploit results from two new academic 'resource centres' - each designed to draw together genetic information and make it available to industry - and on the conditions for such exploitation.

Ministry officials say they are optimistic the negotiations will be concluded successfully by Christmas. But at present, the programme is unlikely to achieve the 50:50 funding split originally proposed by the research minister, Jürgen Rüttgers, when the programme was initially proposed. At its launch last June, he said the programme was only likely to be effective "if industry makes a major contribution".

The genome programme is being set up by the ministry of research (BMBF), and has been promised a total of DM400 million (US\$286 million) over the next eight years. It will include two resource centres, one at the Max Planck Institute (MPI) for Molecular Genetics in Berlin and the other at the German Cancer Research Centre (DKFZ) in Heidelberg.

The MPI has already been awarded DM20 million over two years for work on automated cloning technology based on a hybridization filter technique developed by its director, Hans Lehrach. The DKFZ will receive DM3 million to expand its gene library, verify the data it contains and establish courses in bioinformatics.

The remaining federal funds will pay for competitive grants for individual projects in any area relating to human genome research. Industry is expected to contribute to some of these projects. It will also assist in the setting up of a channel for applying the genetic information identified in the resource centres to the development of drugs and diagnostic techniques.

The programme is already proving popular with the academic community. According to Frank Laplace, the BMBF official responsible for the genome programme, more than 250 grant applications were received by the August deadline. These have revealed in particular a strong interest in analysing the function of gene sequences rather than in large-scale sequencing itself - and in bioinformatics.

The volume of applications, as well as a complicated system of evaluation which includes assessment by an international panel, means that the money is unlikely to be distributed before the middle of next year, even though it had been hoped that the programme would start operating sooner.

The delay is expected to allow time for agreement to be reached on industry's relationship with the work of the two resources centres. Originally, the research ministry had proposed that a private company should be set up, fully owned and financed by industry, to negotiate agreements with the centres on behalf of individual companies.

But this model was dropped after running into legal difficulties: in particular, because the service resource centres are supported by public funds, they cannot negotiate directly with outside bodies, but need the agreement of both their federal and regional funding bodies. Furthermore, the companies originally in favour of the model could not agree on how it should operate.

The ministry is now considering a second model, a so-called Gesellschaft bürgerlichen Rechts, which would have similar legal status to a private corporation, but whose financing and administration would be shared by the centres and interested companies.

Despite delays in reaching overall agreement, informal consensus has already emerged on some specific points. One, for example, is that any patents arising from research at the resource centres would remain the property of the centres. Another point on which most industrial participants are keen is that they should have privileged access to research results emerging from the two resource centres for three months before they are published.

The companies argue that they need reasonable time to assess the potential value of the research results. But their demand is viewed with concern by the MPI and DKFZ, which feel one month of prior access should be sufficient for a company to establish an interest in a particular genetic sequence.

In addition, not all companies are happy with the way the genome programme limits the choice of sequencing methodology to Lehrach's hybridization filter technique. Many companies would also like to see investment in other types of technology, such as the large-scale sequencing techniques used in the United States, of which several have direct experience as a result of collaborative projects with US companies.

In contrast to their apparent reluctance to invest funds in domestic projects, German companies continue to make substantial investments in gene technology in the United States. Earlier this year, for example, Boehringer Ingelheim announced collaboration worth nearly US $\$ 70$ million with Sequana Therapeutics, based in La Jolla, California, which has identified candidate genes for asthma.
Bayer - which is holding back from any investment in the domestic programme - is investing the same sum in Myriad Genetics, in Salt Lake City, Utah, for work on genes related to obesity, osteoporosis and asthma. And earlier this month, Hoechst announced collaboration with Cell Genesys, in California (see opposite), worth up to US\$160 million in the US company's gene therapy programme for HIV infection, based on T-cells, which is now entering phase 2 clinical studies.

Such deals suggest that German industry considers its domestic resource centres to be lagging far behind their US counterparts, and does not regard them as their first choice of research partners. Nevertheless, around 15 companies have already expressed various degrees of interest in participating in the programme. Laplace's main regret is that those least convinced by the programme's priorities are the small genebased companies such as SoftGene, a bioinformatics company based in Berlin.

Bernhard Wittig, managing director of SoftGene, claims that the genomics programme should adopt a more imaginative approach, including such projects as using artificial intelligence for pattern recognition of DNA sequences, in which his company might be interested.

Given the broader picture, Rüttger's claim that the German human genome programme will "make Germany the leading force [in genomics] in Europe by 2000" appears ambitious. But Laplace remains optimistic that the new programme will provide a solid basis for a domestic genomics industry to grow in the near future.

Robert Unterhuber

\section{Optimism returns}

London. After a sustained period of retrenchment, rationalization and falling stock prices, the biotechnology market appears to have recovered its confidence, and may be heading for a new period of sustained growth, according to investment analysts on both sides of the Atlantic.

Last year, the biotechnology industry experienced a number of reversals including in particular the failure of several promising drugs during the early stage of clinical trials - that led to a collapse in the value of many stocks, particularly those in some smaller companies, and an overall loss in investor confidence.

But this difficult period, which saw a number of large pharmaceutical companies stepping in to provide the experience lacking in start-up operations, seems to have been reversed in the past six months, according to Jeremy Curnock Cook, director of Rothschild Asset Management 